\title{
UPAYA MENINGKATKAN MINAT MATEMATIKA DENGAN MODEL PEMBELAJARAN KOOPERATIF TIPE TEAM ASSISTED INDIVIDUALIZATION (TAI)
}

\author{
Oleh: \\ Ika Septi Hidayati \\ SD Negeri Prembulan dan Universitas Cokroaminoto Yogyakarta \\ Email: ikasepti58@gmail.com
}

\begin{abstract}
Abstrak
Tujuan Penelitian ini adalah (1) Mengetahui penerapan model pembelajaran kooperatif tipe team assisted Individualization (TAI) yang tepat agar dapat meningkatkan minat belajar siswa kelas III SD Negeri Prembulan Galur Kulon Progo. (2) Mengetahui kelebihan dan kekurangan model pembelajaran kooperatif tipe team assisted Individualization (TAI) dalam meningkatkan minat belajar siswa kelas III SD Negeri Prembulan Galur Kulon Progo. (3) Mengetahui efektifitas model pembelajaran kooperatif tipe team assisted Individualization (TAI) dalam meningkatkan minat belajar siswa kelas III SD Negeri Prembulan Galur Kulon Progo. Hasil penelitian ini menunjukan bahwa: (1) Secara umum penerapan model pembelajaran TAI yang tepat, efektif dalam meningkatkan minat belajar matematika, (2) Peningkatan minat belajar matematika siswa kealas III SD Prembulan pada pra siklus sebesar 64 pada siklus I sebesar 76,04 pada siklus II sebesar 85,93.
\end{abstract}

Kata Kunci: Team Assisted Individualization, Minat

\begin{abstract}
The purpose of this study are (1) To find out the application of the right type of team assisted Individualization (TAI) cooperative learning model in order to increase the interest in learning of third grade students of Prembulan Galur Kulon Progo State Elementary School. (2) Knowing the strengths and weaknesses of the team assisted Individualization (TAI) type of cooperative learning model in increasing the interest in learning for students in grade III at Prembulan Galur Kulon Progo State Elementary School. (3) Determine the effectiveness of the team assisted Individualization (TAI) type of cooperative learning model in increasing the interest in learning of third grade students of Prembulan Galur Kulon Progo State Elementary School. The results of this study indicate that: (1) In general, the application of an appropriate TAI learning model, effective in increasing interest in learning mathematics, (2) Increasing students' interest in learning mathematics towards Elementary School Prembulan III in pre-cycle of 64 in cycle I amounted to 76.04 in second cycle of 85.93.
\end{abstract}

Keywords: Team Assisted Individualization, Interest

\section{PENDAHULUAN}

Menurut Munadi (2013.p.1) pendidikan sebagai bagian dari kebudayaan merupakan sarana penerus nilai-nilai dan gagasan-gagasan sehingga setiap orang mampu berperan serta dalam transformasi nilai demi kemajuan bangsa dan negara. Untuk mewujudkan tujuan pendidikan yang berkualitas, salah satu yang harus ada adalah guru yang berkualitas. Guru 
yang berkualitas adalah guru yang memiliki kemampuan untuk mewujudkan tujuan pendidikan nasional, yakni yang memiliki kompetensi pedagogik, kompetensi kepribadian, kompetensi sosial, dan kompetensi profesional (UU RI Nomor 14 Tahun 2005 tentang Guru dan Dosen). Dalam melaksanakan kompetensi pedagogik guru dituntut memiliki kemampuan secara metodologis dalam hal perencanaan dan pelaksanaan pembelajaran. Termasuk di dalamnya penguasaan dalam penggunaan media pembelajaran. Penggunaan media atau alat bantu disadari oleh banyak praktisi pendidikan sangat membantu aktivitas proses pembelajaran baik di dalam maupun di luar kelas, terutama membantu peningkatan prestasi belajar siswa. Gurulah yang terlibat langsung dalam upaya memengaruhi, membina, dan mengembangkan kemampuan siswa supaya menjadi cerdas, terampil, dan bermoral tinggi serta berjiwa sehingga siswa mampu mandiri sebagai makhluk individu maupun sosial. Selain guru, aspek yang paling memengaruhi keberhasilan pencapaian kompetensi yaitu cara atau metode guru dalam menyampaikan materi pembelajaran. Dalam implementasinya tidak banyak guru yang memanfaatkannya, bahkan penggunaan metode ceramah (lecture method) monoton masih cukup populer di kalangan guru dalam proses pembelajarannya (Munadi, 2013.p.2) sehingga proses pembelajaran menjadi pasif dan kurang bermanfaat.

Matematika merupakan salah satu mata pelajaran yang telah diajarkan kepada siswa sejak sekolah dasar, bahkan sebelum masuk ke sekolah formal seorang anak telah dikenalkan dengan matematika berupa hitung-hitungan yang sederhana sampai yang dianggap sulit dalam kehidupan sehari-harinya. Paradigma yang berkembang sampai saat ini baik di masyarakat maupun di lingkup para siswa terhadap mata pelajaran matematika adalah matematika merupakan mata pelajaran yang sukar, membosankan dan bisa dikatakan menakutkan. Hal tersebut dapat terlihat dari rendahnya prestasi hasil belajar matematika yang diperoleh rata-rata siswa di semua tingkat pendidikan dari tingkat sekolah dasar sampai tingkat sekolah menengah atas (Sukaryanto, 2012.p.1).

Matematika adalah salah satu cabang ilmu yang sangat penting. Matematika merupakan salah satu cabang ilmu yang sangat penting. Demikian pentingnya, sehingga matematika dijuluki sebagai Queen of Sciences, ratunya para ilmu, sekaligus juga pelayannya (Sutrisman dan G Tambunan, 1987.p.2-4). Matematika sebagai ratu artinya bahwa matematika adalah sebagai sumber dari ilmu pengetahuan lain. Matematika tumbuh dan berkembang untuk dirinya sendiri sebagai suatu ilmu dan tidak tergantung pada ilmu-ilmu lain. Matematika dikembangkan oleh beberapa matematikawan yang mencintai dan belajar matematika hanya sebagai hobi tanpa mempedulikan fungsi dan manfaatnya untuk ilmu-ilmu lain. Tetapi dengan berkembangannya teknologi, banyak 
cabang-cabang matematika murni yang kemudian diterapkan juga dalam berbagai ilmu pengetahuan lain. Oleh karena itu, matematika juga disebut sebagai pelayan ilmu yang lain, karena matematika sering dipakai untuk membantu mempermudah penyelesaian permasalahan yang ada di dalam ilmu-ilmu lain. Matematika juga merupakan prasyarat untuk mempelajari beberapa pelajaran lainnya. Dengan belajar matematika, kita dilatih untuk senantiasa berpikir logis dan kritis dalam memecahkan permasalahan. Pentingnya matematika, dapat kita lihat di sekolah-sekolah sering kali mendapatkan jam pelajaran yang lebih banyak di bandingkan dengan mata pelajaran lainnya. Matematika diajarkan bukan hanya untuk mengetahui dan memahami apa yang terkandung di dalam matematika itu sendiri, tetapi pada dasarnya matematika diajarkan untuk membantu melatih pola pikir siswa agar dapat memecahkan masalah secara kritis, logis, dan tepat. Mempelajari matematika membutuhkan symbol-simbol agar ide-ide atau konsep dapat dikomunikasikan. Banyaknya simbol yang digunakan terkadang membuat siswa pusing dan merasa bahwa matematika itu merupakan pelajaran yang paling sulit. Terlebih lagi para guru matematika biasanya menggunakan metode yang monoton yaitu ceramah yang cenderung membosankan sehingga membuat siswa semakin kesulitan dalam mempelajari matematika. Keberhasilan seorang siswa dalam mempelajari matematika ditandai dengan prestasi belajar. Prestasi belajar seorang siswa akan dipengaruhi oleh banyak faktor baik dari dalam diri siswa maupun dari luar diri siswa. Salah satu faktor dari dalam adalah minat belajar matematika, disamping adanya faktor tersebut juga ada kaitannya dengan faktor intelegensi yaitu penalaran. Sedangkan faktor dari luar diri siswa (eksternal) antara lain kebiasaan belajar, media komunikasi (televisi, radio, internet dll), fasilitas belajar, manajemen sekolah dan sebagainya (Thursan Hakim, 2012.p.6). Minat memegang peranan penting dalam proses belajar mengajar.. Dalam kenyataannya tidak semua siswa belajar karena didorong oleh faktor minatnya sendiri, ada yang mengembangkan minatnya terhadap materi pelajaran dikarenakan pengaruh dari gurunya, temannya, atau orang tuanya. Oleh sebab itu, sudah menjadi kewajiban dan tanggung jawab guru untuk mengkondisikan kelas yang bisa membangkitkan minat siswa untuk belajar.

Berdasarkan informasi dari guru kelas III setempat serta observasi langsung, permasalahan yang timbul pada pembelajaran matematika di SD Negeri Prembulan Galur Kulon Progo adalah rendahnya minat belajar matematika siswa kelas III. Dalam mengikuti proses pembelajaran matematika sebagian siswa tidak memperhatikan penjelasan guru, terutama siswa yang duduk di bangku belakang. Mereka sering mengobrol dengan teman sebangku dan melamun. Kondisi tersebut kurang diketahui oleh 
guru, karena guru lebih dominan di depan kelas menerangkan materi pelajaran, kecuali siswa yang ribut di kelas langsung mendapat teguran dari guru.

Agar dapat membangkitkan minat belajar siswa seorang guru harus benar-benar bisa menguasai semua keterampilan yang menyangkut pengajaran, keterampilan ini sangat mempengaruhi minat belajar siswa seperti halnya dalam memilih model pembelajaran yang tepat dalam mengajar sehingga siswa dapat dengan mudah memahami dan menguasai materi yang disampaikan guru. Salah satunya guru dapat menerapkan model pembelajaran Team Assisted Individualization Melalui model pembelajaran kooperatif tipe Team Assisted Individualization (TAI) akan terjadi diskusi antara siswa dalam satu kelompok untuk memahami secara bersama-sama suatu konsep matematika. Sehingga tumbuh kerja sama antar anggota kelompok dalam usaha membantu memecahkan masalah bagi anggota kelompok kecil pada model pembelajaran kooperatif tipe Team Assisted Individualization (TAI), guru memberikan perhatian kepada siwa sehinggga terjadi hubungan yang lebih akrab antara guru dengan siswa maupun siswa dengan siswa lain. Pembelajaran kelompok merupakan salah satu strategi untuk meningktakan minat belajar matematika.

Melihat kenyataan dalam observasi di SD Negeri Prembulan Galur Kulon Progo maka peneliti tertarik untuk melakukan penelitian dengan judul "Upaya Meningkatkan Minat Belajar Matematika dengan Model Pembelajaran Team Assisted Individualization (TAI) pada Siswa Kelas III SD Negeri Prembulan Galur Kulon progo”.

1. Teori yang digunakan

a. Minat Belajar

Minat belajar terdiri dari dua kata yakni minat dan belajar. Menurut Winkel (2004.p.212) minat adalah kecenderungan subjek yang menetap, untuk merasa tertarik pada bidang studi atau pokok bahasan tertentu dan merasa senang mempelajari materi itu. Menurut Arifin (2011.p.241) minat adalah dorongan atau aktivitas mental yang dapat merangsang perasaan senang terhadap sesuatu. Berminat tidaknya seseorang terhadap sesuatu dapat dilihat dari beberapa indikator yaitu perhatian, perasaan, motivasi, dan sikap. Sementara itu Slameto (2013.p.57) mengatakan minat adalah kecenderungan yang tetap untuk memperhatikan dan mengenang beberapa kegiatan, kegiatan yang diminati, diperhatikan terus-menerus yang disertai dengan rasa senang. Minat besar pengaruhnya terhadap belajar karena bila bahan pelajaran yang dipelajari tidak sesuai dengan minat siswa, siswa tidak akan belajar dengan sebaik-baiknya karena tidak ada 
daya tarik baginya. Bahan pelajaran yang menarik minat siswa, lebih mudah dipelajari dan disimpan karena minat menambah kegiatan belajar.

Menurut Hamalik (2008.p.154-155) belajar adalah perubahan tingkah laku yang relatif mantap berkat latihan dan pengalaman. Belajar sesungguhnya adalah ciri khas manusia dan membedakannya dengan binatang. Belajar yang dilakukan oleh manusia merupakan bagian dari hidupnya, berlangsung seumur hidup, kapan saja, dan di mana saja baik di sekolah, di kelas, dan di jalanan dalam waktu yang tidak dapat ditentukan sebelumnya. Hasil belajar tampak sebagai terjadinya perubahan tingkah laku pada diri siswa yang dapat diamati dan diukur dalam bentuk perubahan pengetahuan sikap dan keterampilan. Perubahan tersebut dapat diartikan terjadinya peningkatan dan pengembangan yang lebih baik dibanding dengan sebelumnya misalnya dari tidak tahu menjadi tahu, sikap kurang sopan menjadi sopan dan sebagainya. Jadi, dapat ditarik kesimpulan bahwa belajar itu menimbulkan suatu perubahan tingkah laku yang relatif tetap dan perubahan itu dilakukan lewat kegiatan atau usaha yang disengaja.

Berdasarkan pendapat di atas yang dimaksud dengan minat belajar adalah aspek psikologi seseorang yang menampakkan diri dalam beberapa gejala seperti gairah, keinginan, perasaan suka untuk melakukan proses perubahan tingkah laku melalui berbagai keinginan yang meliputi mencari pengetahuan dan pengalaman. Dalam minat belajar itu ada perhatian, perasaan suka, motivasi sebagai pendorong belajar, dan sikap dalam belajar.

\section{b. Pembelajaran Kooperatif}

Pembelajaran adalah setiap upaya yang dilakukan dengan sengaja oleh pendidik yang dapat menyebabkan peserta didik melakukan kegiatan belajar (Nana Sudjana, 2001.p.80). Sedangkan kooperatif berasal dari bahasa Inggris yaitu Cooperate yang berarti bekerja bersama-sama. Pembelajaran kooperatif adalah suatu model pembelajaran dimana siswa belajar dan bekerja dalam kelompok-kelompok kecil secara kolaboratif yang anggotanya 4-6 orang dengan struktur kelompok heterogen (Robert E. Slavin, 2011.p.8). Pendapat lain tentang pembelajaran kooperatif adalah strategi belajar dengan sejumlah siswa sebagai anggota kelompok kecil yang tingkat kemampuannya berbeda (Isjoni, 2009.p.14). Pembelajaran kooperatif mencakup siswa yang bekerja dalam kelompok kecil untuk menyelesaikan masalah, menyelesaikan suatu tugas atau mengerjakan sesuatau untuk mencapai tujuan bersama lainnya (Erman Suherman, 2003.p.260). Berdasarkan pernyataan di atas dapat disimpulkan bahwa pembelajaran kooperatif merupakan model pembelajaran yang dilakukan dalam kelompok-kelompok 
kecil dimana dalam kelompok tersebut diharapkan siswa dapat bekerjasama satu sama lainnya untuk belajar materi-materi akademik, sehingga proses belajar mengajar dapat berjalan dengan lancar.

Unsur-unsur dasar pembelajaran kooperatif (Muslim Ibrahim, 2001.p.5-6), yaitu:

a) Setiap anggota kelompok beranggapan bahwa mereka sehidup sepenanggungan bersama.

b) Siswa bertanggung jawab atas segala sesuatu didalam kelompoknya seperti mereka bertanggung jawab atas diri mereka sendiri.

c) Siswa harus melihat bahwa semua anggota di dalamnya memiliki tujuan yang sama.

d) Siswa harus membagi tugas dan tanggung jawab yang sama di antara anggota kelompok.

e) Siswa akan dievaluasi dan diberi penghargaan secara kelompok.

f) Siswa berbagi kepemimpinan dan membutuhkan keterampilan untuk dapat belajar bersama selama pembelajaran.

g) Siswa akan diminta pertanggung jawaban secara individu dalam kelompok pembelajaran kooperatif.

Pembelajaran kooperatif memiliki ciri-ciri (Muslimin Ibrahim, 2001.p.7-11), sebagai berikut:

a) Siswa bekerja dalam kelompok secara kooperatif untuk menuntaskan materi belajarnya.

b) Kelompok dibentuk darin siswa yang memiliki kemampuan tinggi, sedang dan rendah.

c) Bilamana mungkin anggota ras terdiri dari ras, budaya, suku, jenis kelamin yang berbeda-beda.

d) Penghargaan lebih berorientasi pada kelompok dari pada individu.

Sintak model pembelajaran kooperatif terdiri dari enam fase (Agus Suprijono, 2012.p.65), yaitu: 
Tabel 1 Fase pembelajaran kooperatif

\begin{tabular}{|l|l|}
\hline \multicolumn{1}{|c|}{ Fase-fase } & \multicolumn{1}{|c|}{ Perilaku guru } \\
\hline $\begin{array}{l}\text { Fase 1: Present goals and set } \\
\text { Menyampaikan tujuan dan } \\
\text { mempersiapkan peserta didik }\end{array}$ & $\begin{array}{l}\text { Menjelaskan tujuan pembelajaran dan } \\
\text { mempersiapkan peserta didik siap belajar }\end{array}$ \\
\hline $\begin{array}{l}\text { Fase 2: Present information } \\
\text { Menyajikan informasi }\end{array}$ & $\begin{array}{l}\text { Mempesentasikan informasi kepada } \\
\text { peserta didik secara verbal }\end{array}$ \\
\hline $\begin{array}{l}\text { Fase 3: Organize students into } \\
\text { learning teams }\end{array}$ & $\begin{array}{l}\text { Memberikan penjelasan kepada peserta } \\
\text { didik tentang tata cara pembentukan tim } \\
\text { Mengorganisir peserta didik ke } \\
\text { dalam tim-tim belajar dan memantu kelompok } \\
\text { melakukan transisi yang efisien }\end{array}$ \\
\hline $\begin{array}{l}\text { Fase 4: Assist team work and } \\
\text { study }\end{array}$ & $\begin{array}{l}\text { Membantu tim-tim belajar selama peserta } \\
\text { didik mengerjakan tugasnya }\end{array}$ \\
\hline $\begin{array}{l}\text { Fembantu 5: Test on the materials } \\
\text { Mengevaluasi }\end{array}$ & $\begin{array}{l}\text { Menguji pengetahuan peserta didik } \\
\text { mengenai berbagai materi pembelajaran } \\
\text { atau kelompok-kelompok } \\
\text { mempresentasikan hasil kerjanya }\end{array}$ \\
\hline $\begin{array}{l}\text { Fase 6: Provide recognition } \\
\text { Memberikan pengakuan atau } \\
\text { penghargaan }\end{array}$ & $\begin{array}{l}\text { Mempersiapkan cara untuk mengakui } \\
\text { usaha dan presentasi individu maupun } \\
\text { kelompok }\end{array}$ \\
\hline
\end{tabular}

Karakteristik pembelajaran kooperatif (Wina Sanjaya, 2010.p.244-246) yaitu:

a) Pembelajaran secara tim.

Tim merupakan tempat untuk mencapai tujuan sehingga tim harus mampu membuat setiap siswa belajar. Semua anggota kelompok harus saling membantu untuk mencapai tujuan pembelajaran.

b) Didasarkan pada manajemen kooperatif.

Sebagaimana umumnya manajemen mempunyai empat fungsi pokok, yaitu fungsi perencanaan, fungsi organisasi, fungsi pelaksanaan dan fungsi kontrol. Demikian juga dalam pembelajaran kooperatif.

c) Kemauan untuk bekerja sama.

Keberhasilan pembelajaran kooperatif ditentukan oleh keberhasilan sebuah kelompok. Oleh sebab itu, setiap anggota kelompok bukan hanya diatur tugas dan tanggung jawab masing-masing, tetapi juga ditanamkan perlunya saling membantu.

d) Keterampilan bekerja sama.

Siswa perlu didorong untuk saling berinteeraksi dan komunikasi, sehingga setiap siswa dapat menyampaikan ide, mengeluarkan pendapat, dan memberikan kontribusi kepada keberhasilan kelompok. 
Pembelajaran koperatif mempunyai keunggulan (Wina Sanjaya, 2010.p.249-250), yaitu:

a) Siswa tidak terlalu menggantungkan pada guru, akan tetapi dapat menambah kepercayaan kemampuan berpikir sendiri.

b) Dapat mengembangkan kemampuan mengungkapkan ide atau gagasan.

c) Dapat memberdayakan siswa untuk merespon orang lain.

d) Dapat meningkatkan prestasi akademik sekaligus kemampuan sosial.

e) Dapat mengembangkan kemampuan siswa untuk menguji ide dan pemahamannya sendiri, menerima umpan balik.

f) Dapat meningkatkan kemampuan siswa menggunakan informasi dan kemampuan belajar abstrak menjadi nyata.

g) Dapat meningkatkan motivasi dan memberikan rangsangan untuk berpikir.

Selain beberapa kelebihan pembelajaran kooperatif juga mempunyai beberapa kelemahan (Wina Sanjaya, 2010.p.250-251), yaitu:

a) Untuk memahami dan mengerti filosofis pembelajaran kooperatif memang butuh waktu.

b) Jika tanpa peer teaching yang efektif, maka kegiatan saling membelajarkan tidak pernah dicapai oleh siswa.

c) Penilaian yang diberikan didasarkan kepada hasil kerja kelompok.

d) Keberhasilan pembelajaran kooperatif dalam upaya mengembangkan kesadaran berkelompok memerlukan periode waktu yang lama.

c. Model Pembelajaran Kooperatif Tipe Team Assisted Iindividualization (TAI)

Pembelajaran kooperatif tipe Team Assisted Individualization (TAI) dikembangkan oleh Slavin. Tipe ini mengkombinasikan keunggulan pembelajaran kooperatif dan pembelajaran individual. Tipe ini dirancang untuk mengatasi kesulitan belajar siswa secara individual. Hasil belajar individual dibawa ke kelompok-kelompok untuk didiskusikan dan saling dibahas oleh anggota kelompok, dan semua anggota kelompok bertanggung jawab atas keseluruhan jawaban sebagai tanggung jawab bersama.

Model pembelajaran Team Assisted Individualization (TAI) memiliki 8 (delapan) komponen (Robert E. Slavin, 2011.p.195-200), sebagai berikut:

a) Teams.

Dalam pembelajaran kooperatif siswa belajar dalam kelompok kecil yang beranggotakan 4-5 orang. Anggota kelompok tersebut merupakan kelompok yang heterogen (jenis kelamin, etnis, suku, budaya dan kemampuan). 
b) Placement test.

Untuk mengetahui kemampuan awal siswa sebagai dasar pertimbangan pengelompokan. Maka siswa dalam tahap ini diberi tes yang berupa pretest atau bisa berupa hasil tes sebelumnya.

c) Teaching group.

Guru menjelaskan materi pokok secara klasikal pada siswa yaitu dengan memperkenalkan konsep-konsep utama pada siswa sebelum mereka mengerjakan tugas secara individu.

d) Student creative.

Sebelum siswa bekerja dalam kelompoknya, terlebih dahulu masing-masing siswa berusaha membaca, memahami materi pelajaran serta mencoba mengerjakan tugas secara individu.

e) Team study.

Para siswa diberikan suatu unit perangkat pembelajaran secara individu yang berisikan materi. Kemudian para siswa mengerjakan dan membahas unit-unit tersebut dalam kelompok masing-masing. Jika ada siswa yang mendapat kesulitan disarankan untuk meminta bantuan dalam kelompok sebelum meminta bantuan kepada guru.

f) Whole class unit.

Pada tahap ini dilakukan diskusi kelas, setiap anggota kelompok mempresentasikan hasil kerja kelompoknya. Maka tugas kelompok lain adalah menanggapi jawaban dari hasil kerja kelompok yang dipresentasikan. Setelah diskusi serta membenahi atau menyempurnakan jawaban siswa. Di akhir diskusi guru meminta siswa untuk membuat kesimpulan.

g) Fact test.

Guru memberikan tes untuk mengukur kemempuan siswa setelah diberi materi. Pada penelitian ini tes diberikan setelah akhir pembelajaran.

h) Team scores and team recognition.

Di akhiri pembelajaran guru menghitung skor kelompok. Skor ini didasarkan pada jumlah rata-rata dari nilai tes anggota kelompok 


\section{METODE PENELITIAN}

Penelitian ini merupakan Penelitian Tidakan Kelas (PTK). Penelitian Tindakan Kelas merupakan suatu penelitian yang akar permasalahannya muncul di kelas dan dirasakan langsung oleh guru yang bersangkutan sehingga sulit dibenarkan jika ada anggapan bahwa permasalahan dalam penelitian tindakan kelas diperoleh dari persepsi atau lamunan seorang peneliti (Arikunto, 2008.p.104). Penelitian ini dilakukan secara kolaboratif artinya peneliti bekerja sama dengan guru mata pelajaran yang bersangkutan sebagai satu tim, terlibat langsung dalam persiapan-persiapan yang diperlukan, refleksi tindakan, dan perencanaan dalam setiap siklus.

Subjek penelitian ini adalah siswa kelas III berjumlah 28 siswa di SD Negeri Prembulan Galur Kabupaten Kulon Progo. Objek penelitian ini adalah minat belajar matematika siswa kelas III SD Negeri Prembulan Galur Kulon Progo. Teknik pengumpulan data pada penelitian ini berupa observasi, angket, dan dokumentasi. Instrumen penelitian ini adalah lembar observasi dan angket.

Observasi dilakukan selama proses pelaksanaan pembelajaran Matematika berlangsung.Angket digunakan untuk mengetahui minat belajar siswa Angket berisi 25 butir soal dan terdiri dari 4 aspek yang diamati perhatian, perasaan, motivasi, dan sikap.. Dalam penelitian untuk menguji instrumen digunakan teknik uji coba terpakai, yaitu mengujicobakan instrumen sekaligus mengumpulkan data penelitian. Komponen-komponen yang menjadi indikator keberhasilan dalam penelitian ini yaitu 80\% minat belajar siswa meningkat menjadi kategori tinggi dengan model pembelajaran Team Assisted Individualization (TAI).

\section{HASIL PENELITIAN DAN PEMBAHASAN}

Deskripsi Hasil

Minat belajar siswa diketahui dengan perhitungan skor angket. Minat belajar siswa meningkat setelah diterapkannya model pembelajaran TAI. Skor rata-rata angket pada siklus I adalah 76,04 dan siklus II mengalami peningkatan yaitu 85,93 dengan kategori minat siswa sangat tinggi.

Peningkatan rata-rata minat belajar kategori tinggi kelas III SD Prembulan dari pra siklus, Siklus I, dan Siklus II sebagai berikut.

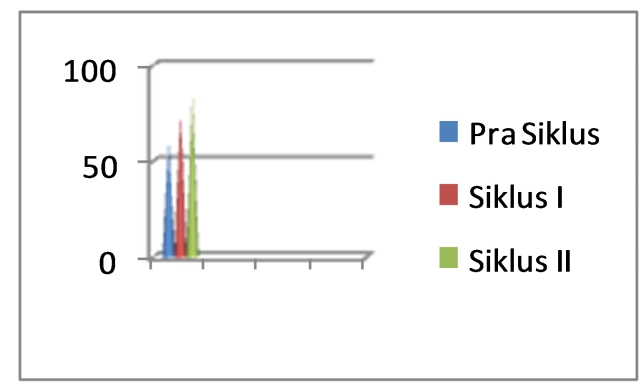


Pembahasan

Berdasarkan dari hasil analisis data-data yang dihimpun dari pelaksanaan penelitian dilapangan, peneliti akan mengemukakan data yang berhasil diperoleh sebagai berikut:

1. Penerapan model pembelajaran Team Assisted Individualization (TAI)

mampu meningkatkan minat belajar matematika.

a. Peningkatan minat belajar matematika

1) Dari hasil pengamatan dari pra siklus, siklus I, siklus II minat siswa dalam pembelajaran matematika meningkat. Siswa memperhatikan pelajaran, antuasias dalam mengikuti pembelajaran, meningkatkan rasa percaya diri dan keaktifan siswa.

2) Dari hasil peningkatan rata-rata skor minat dari pra siklus, siklus I, siklus II minat siswa dalam pembelajaran matematika meningkat. Dilihat dari pra siklus 64 siklus I memperoleh 76,04 dan siklus II memperoleh 85,93.

b. Penerapan tindakan yang tepat dapat meningkatkan minat belajar, dilakukan memperhatikan sintaks yang telah disesuaikan dengan memperhatikan hal-hal sebagai berikut:

1) Guru dapat memberikan tugas yang bervariasi dan membentuk susunan kelompok baru agar siswa tidak merasa jenuh

2) Siswa dibiasakan untuk diskusi kelompok agar dapat berperan aktif dalam pembelajaran sehingga ketekunan, keuletan, dorongan untuk berprestasi, dan usaha untuk berprestasi akan lebih terlihat.

3) Setelah siswa diberi tes alangkah baiknya setelah selesai dikoreksi dan dinilai, hasil pekerjaan siswa dibagikan kembali kepada siswa supaya siswa merasa puas dan termotivasi untuk meningkatkan hasil belajarnya.

2. Kelebihan kelemahan model pembelajaran TAI dalam penelitian ini adalah:

a. Kelebihan

1) Meningkatkan minat belajar siswa.

2) siswa menjadi lebih aktif.

3) Siswa yang lemah dapat dibantu oleh siswa pandai

b. Kekurangan:

1) Siswa yang lemah tergantung dengan siswa pandai

2) Siswa lemah kurang aktif

3. Uji efektifitas dalam penelitian ini difungsikan untuk menganalisa keefektifan tindakan penerapan model pembelajaran Team Assisted Individualization (TAI) di kelas III SD Muhammadiyah Ledok dengan kelas III SD Negeri Bekelan. 
a. Uji Kesetaraan

Hasil uji kesetaraan disimpulkan tidak ada perbedaan yang signifikan rata-rata nilai UAS antara kelas III SD Muhammadiyah Ledok (Kelompok model TAI) dengan kelas III SD Negeri Bekelan (Kelompok konvensional).

b. Uji Beda Minat Belajar Matematika

Berdasar hasil uji beda minat belajar ada perbedaan secara signifkan rata-rata minat belajar matematika antara kelas III SD Muhammadiyah Ledok (Kelompok model pembelajaran TAI) dengan kelas III SD Negeri Bekelan (Kelompok model pembelajaran konvensional).

\section{DAFTAR PUSTAKA}

Agus, Suprijono. 2012. Cooperative Learning : Teori \& Aplikasi Paikem. Yogyakarta: Pustaka Pelajar.

Arifin, Zainal. 2011. PenelitianPendidikan Metode dan Paradigma Baru. Bandung: PT Remaja Rosdakarya.

Arikunto, dkk. 2008. Penelitian Tindakan Kelas. Jakarta: Bumi Aksara.

Hamalik, Oemar. 2008. Perencanaan Pengajaran Berdasarkan Pendekatan Sistem. Jakarta: PT Bumi Aksara.

Isjoni. 2009. Cooperative Learning. Bandung: Alfabeta

Krismanto. 2003. Beberapa Teknik, Model dan Stategi dalam Pembelajaran Matematika. Yogyakarta: Departemen Pendidikan Nasional Direktorat Jenderal Pendidikan Dasar dan Menengah Pusat Pengembangan Penataan Guru (PPPG) Matematika.

Munadi, Yudhi. 2013. Media Pembelajaran. Jakarta: GP Press Group.

Muslim Ibrahim. 2001. Pembelajaran Kooperatif. Surabaya: UNESA-UNIVERSITI PERSS.

Purtini.2016. Peningkatan motivasi dan Prestasi Belajar Siswa dalam Pembelajaran Matematika melalui Penerapan Model Pembelajaran Kooperatif Jigsaw Di SMA N 1 Ngaglik Sleman Tahun Ajaran 2015/2016

Robert E. Slavin. 2011. Cooperative Learning. Bandung: Nusa Media

Slameto. 2013. Belajar dan Faktor-faktor yang Mempengaruhinya. Jakarta: Rineka Cipta

Sudjana, Nana. 2001. Dasar-Dasar Proses Belajar Mengajar. Bandung: Sinar Baru

Suherman, Erman. 2003. Strategi Pembelajaran Matematika Kontemporer (Edisi Revisi). Bandung: JICA-UPI. 
Sukaryanto, 2012. Upaya Meningkatkan Keaktifan dan Prestasi Belajar Matematika Dengan Metode Pembelajaran Kooperatif Tipe Group Investigation (GI) Siswa Kelas VII B SMP Taman Dewasa Ibu Pawiyatan Yogyakarta Tahun Ajaran 2011/2012. Skripsi Universitas Sarjanawiyata Tamansiswa.

Syaiful Bahri Djamarah. 2012. Prestasi Belajar dan Kompetensi Guru. Surabaya: Usaha Nasional

Thursan Hakim. 2012. Belajar Secara Efektif. Jakarta: Pustaka Pembangunan Swadaya Nusantara.

Winkel, S J. 2004. Psikologi Pengajaran. Yogyakarta: Media Abadi.

Wina Sanjaya. 2010. Strategi Pembelajaran Berorientasi Standar Proses Pendidikan. Jakarta: Prenada. 